\title{
Chapter 2 \\ The Future of Work: Is This Time Different?
}

\author{
Carl Benedikt Frey
}

The key point I would like to make is that, even though I am confident that there will be enough jobs to go around in the next decades, there are transitional and social costs associated with technological progress. As I argue in my forthcoming book, The Technology Trap: Capital, Labor, and Power in the Age of Automation, technological change is welfare-improving but not Pareto-improving, at least in the short run. And as the experience of the British Industrial Revolution illustrates, what economists regard as the short run can be a lifetime. The Industrial Revolution was also a time when there was significant resistance to technological change. And to avoid such resistance, governments need to manage the short run and provide people with the right skills.

The second point is that for the emerging world, cheap labor will soon no longer constitute a comparative advantage. We see new jobs emerging-primarily skilled ones - and those tend to overwhelmingly cluster in places that already have an educated workforce.

It may be said by the commentator Frederick Soddy that civilization is pursuing two precisely opposite goals at one and the same time. On Mondays, Wednesdays, and Fridays it invents new methods of abolishing labor, and on Tuesdays, Thursdays, and Saturdays new labors to relieve the consequent unemployed.

If we look back historically, there can be no doubt that we have been extraordinarily productive on Mondays, Wednesdays, and Fridays. Few readers will know anybody who works as a lamplighter, elevator operator, or switchboard operator. And looking only at the occupations that have vanished hugely understates that the transformation has happened in advanced economies.

\footnotetext{
C. B. Frey $(\bowtie)$

Oxford Martin Citi Fellow and Director of Technology and Employment, Oxford Martin School, Oxford University, Oxford, UK

e-mail: carl.frey@oxfordmartin.ox.ac.uk
}

B. Panth and R. Maclean (eds.), Anticipating and Preparing for Emerging Skills and Jobs, Education in the Asia-Pacific Region: Issues, Concerns and Prospects 55, https://doi.org/10.1007/978-981-15-7018-6_2 
Think of the work of a farm laborer in 1900. If you were to take that person onto a modern farm, he would for the first time in his life encounter tractors, automobiles, electricity, global positioning system or GPS technology, milking machines, computers, and so on. It would probably take years to train him. In fact, I would go as far as to suggest that nearly all jobs that existed in 1900 have already disappeared. The occupational titles that remain from that time exist only on paper. Their content has changed so dramatically that they are almost no longer recognizable.

The potential scope of automation has expanded significantly over the centuries. If we go back a hundred years, distinguishing between humans and computers was meaningless. Humans were computers; computer was an occupation specializing in basic arithmetic, and tabulating the results. Since then, automation has largely been confined to rule-based activities that can easily be specified in computer code. But what we are seeing now is that — for the very first time — computers are actually able to learn themselves. Instead of having a programmer specifying what a computer should do at any given contingency, we can use bottom-up machine learning. According to our estimates, roughly $47 \%$ of jobs are at high risk of automation as a consequence.

So what does this mean for the future? Some people have taken our estimates to suggest that we can all just retire and enjoy a life of leisure and fulfillment. But we could have decided to do that a long time ago. In the United States, for example, over the past century, labor productivity has grown by $800 \%$, while leisure time has increased only by $10 \%$. The main reason is that we are greedy-for lack of a better word. Most people are very happy to work long hours to go to those hot yoga classes, stay at nice hotels, and travel around the world. And as long as there is demand for things that only humans can produce, I predict there will still be jobs to go around.

A much greater concern is that the labor share of national incomes has fallen across the board. Even before the days of strong labor unions, compensation was growing roughly in tandem with productivity. But since the Computer Revolution of the 1980s, we see that a gap has emerged between productivity and compensation.

While most research has focused on advanced economies, when I worry about this, I actually worry primarily about developing economies. The reason is what the economist Dani Rodrik has called premature de-industrialization. The way that countries like the United States, Germany, and the United Kingdom got rich was simply by shifting low-skill workers from agriculture into routine manufacturing. But that route to prosperity might not be open in developing countries going forward as the automation of factory work progresses.

At the same time, we see that new jobs are emerging as new technologies are being introduced, but those are jobs primarily for the highly skilled. If we take new industries that have emerged since 2000, we find that most of them relate to digital technologies or biotech. And we find that the workers in those industries are much more likely to have a college degree or a STEM degree.

However, these tech jobs also support many jobs in the local service economy: In the United States, for example, one high-tech job creates five new jobs in the nontrader sector in a given city. And our research shows that the multiplier is even higher in most developing countries. 
By leapfrogging industrialization to the high-tech economy, a lot of demand for the new jobs can actually be created in the local service economy. And I believe that is the route that the next generation of emerging economies needs to follow. They need to leapfrog industrialization by investing in human capital and new industries. The main priority of development banks should, therefore, be to invest in people's skills rather than physical capital.

Link to the presentation material: https://events.development.asia/materials/201 71212/future-work-time-different.

The views expressed in this Chapter are those of the authors and do not necessarily reflect the views and policies of the Asian Development Bank (ADB) or its Board of Governors or the governments they represent.

ADB does not guarantee the accuracy of the data included in this Chapter and accepts no responsibility for any consequence of their use. The mention of specific companies or products of manufacturers does not imply that they are endorsed or recommended by ADB in preference to others of a similar nature that are not mentioned.

By making any designation of or reference to a particular territory or geographic area, or by using the term "country" in this Chapter, ADB does not intend to make any judgments as to the legal or other status of any territory or area.

This work is available under the Creative Commons Attribution 3.0 IGO license (CC BY 3.0 IGO) https://creativecommons.org/licenses/by/3.0/igo/. By using the content of this Chapter, you agree to be bound by the terms of this license. For attribution, translations, adaptations, and permissions, please read the provisions and terms of use at https://www.adb.org/terms-use\#openac cess.

This CC license does not apply to non-ADB copyright materials in this Chapter. If the material is attributed to another source, please contact the copyright owner or publisher of that source for permission to reproduce it. ADB cannot be held liable for any claims that arise as a result of your use of the material.

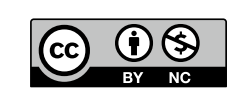

